\title{
Dissociation of Aggregated IgG and Denaturation of Monomeric IgG by Acid Treatment
}

\author{
Yahiro Uemura \\ Department of Bacteriology, Tohoku University School of \\ Medicine, Sendai 980
}

Uemura, Y. Dissociation of Aggregated IgG and Denaturation of Monomeric IgG by Acid Treatment. Tohoku J. exp. Med., 1983, 141 (3), 337-349 Conditions for obtaining a large quantity of monomeric $\operatorname{IgG}$ which can be used for intravenous injections in humans was successfully established with human serum IgG preparation obtained using the ethanol fractionation method. When dissociation of IgG aggregates and denaturation of IgG monomers contained in the starting material were examined at various $\mathrm{pH}$ values, the treatment for 60 min at $28^{\circ} \mathrm{C}$ at $\mathrm{pH} \quad 3.8-4.0$ was found to be optimum for obtaining such monomeric $\operatorname{IgG}$. At this $\mathrm{pH}$ range, the dissociation of $\operatorname{IgG}$ aggregates into monomeric IgG reached maximum, without producing polymeric IgG. When monomeric IgG was treated at this acidic $\mathrm{pH}$ condition, its biological and physicochemical properties such as acid difference spectrum, molecular weight, plasmic digestion ratio, and complement-, antigen- and protein A-binding activities remained unchanged. The fact that large scale production of monomeric IgG can be easily performed under such conditions is discussed.—- dissociation; denaturation; human IgG; acid treatment

Conventional intramuscular immunoglobulin (IgG) preparations obtained by cold ethanol or ammonium sulfate fractionation methods contain IgG aggregates. The aggregates have some biological activities such as anticomplemental and antigenic activities (Ishizaka and Ishizaka 1959; Christian 1960; Henney and Ellis 1968) and may evoke anaphylactoid reactions, particularly in immunodeficient patients. Therefore, its intravenous use has to be strictly avoided.

Several methods have been reported for the elimination or dissociation of the aggregates to obtain IgG preparations suitable for intravenous use. Acid treatments is one of the methods for the dissociation of the aggregates. Earlier experimental results (Hansson 1968) showed that aggregated human IgG was dissociated by acid treatment at $\mathrm{pH} 3.0$ in the presence of glycine. But the question was, to what extent did such acid treated IgG retain its biological as well as physicochemical properties. Analysis of human IgG by circular dichroism (CD) (Doi and Jirgensons 1970) showed that IgG after acid treatment at $\mathrm{pH} 2.2$ differed slightly from untreated IgG. Further studies on the biological properties of IgG under other $\mathrm{pH}$ conditions have not been performed. Biological properties

Received for publication, April 1, 1983.

Reprint requests: Y. Uemura, Central Research Laboratory, The Green Cross Corporation, 3-5-44, Miyakojima, Nakadori, Miyakojimaku, Osaka, 534. 
of acid treated rabbit IgG were studied at various $\mathrm{pH}$ conditions by Stollar et al. (1976). In their report, complement binding activity decreased after treatment at $\mathrm{pH} 3.0$ but the antigen binding activity survived after the same treatment.

Since rabbit IgG differs from human IgG in its sensitivity to proteases (Hsiao and Putnam 1961) and in the properties of its fragments (Fey 1975), the author attempted to study the biological and physicochemical properties of human monomeric and aggregated IgG molecules before and after acid treatment in detail. The purpose of this paper is to describe the molecular weight, acid difference spectrum, sensitivity against plasmin, and complement-, antigen- and protein A-binding activities of human IgG before and after acid treatment at various $\mathrm{pH}$ values.

\section{Materials ANd Methods}

\section{Human $\operatorname{Ig} G$}

Human IgG was isolated from normal human plasma by the cold ethanol fractionation method.

$H B s A g$

Purified HBsAg was obtained using both polyethylene glycol (PEG) fractionation and ultracentrifugation (Funakoshi et al. 1981).

\section{Lipopolysaccharide}

Lipopolysaccharide (LPS) of Pseudomonas aeruginosa F-1 was purified by the phenol-water extraction method (Westphal et al. 1952).

Complement Tokyo.

Lyophilized guinea pig serum complement was purchased from Kyokuto Seiyaku,

\section{Human plasmin}

Plasminogen purified from Cohn's Fr-III paste of human plasma by the lysineSepharose method (Deutsch and Mertz 1970) was activated by passage through the urokinase-conjugated Sepharose column. The proteolytic activity of the plasmin was determined by the caseinolytic method (Sgouris et al. 1961)

\section{Gel filtration}

Isolation of IgG aggregates and IgG monomer fractions was performed on a Sephadex G-200 column $(2.5 \times 90 \mathrm{~cm})$. Six $\mathrm{ml}$ of $5 \% \mathrm{IgG}$ in $0.075 \mathrm{M}$ phosphate buffer $(\mathrm{pH} 7.0)$ containing $0.075 \mathrm{M} \mathrm{NaCl}$ (PBS) was passed through the column at a flow rate of $25 \mathrm{ml} / \mathrm{hr}$ and at $4^{\circ} \mathrm{C}$. Fraction was collected in $6.7 \mathrm{ml}$ and the absorbance at the $280 \mathrm{~nm}$ was determined with a Shimazu UV-240 spectrophotometer. Analysis of the relative amount of IgG aggregates and the monomer was done by the high performance liquid chromatography (HPLC) method. SWP $(7.5 \mathrm{~cm})$ was used as a precolumn and $3,000 \mathrm{SW}(120 \mathrm{~cm})$ was used as a fractionation column (Toyo Soda Manufacturing, Tokyo). Both SWP and 3,000 SW were equilibrated with $0.05 \mathrm{M}$ acetate buffer containing $0.3 \mathrm{M} \mathrm{NaCl}, \mathrm{pH}$ 6.5. A sample solution $(25 \mu \mathrm{l})$ was passed through the columns at a flow rate of $1 \mathrm{ml} / \mathrm{min}$.

\section{Acid treatment}

To $3 \mathrm{ml}$ of IgG solution $(1.4-7.0 \mathrm{mg} / \mathrm{ml})$ in $0.05 \mathrm{M} \mathrm{KCl}$ containing $0.2 \%$ PEG $\$ 4,000,0.1$ $\mathrm{ml}$ of $\mathrm{HCl}$ solution (up to $0.1 \mathrm{~N}$ ) was added for $\mathrm{pH}$ adjustment. After the acid treatment, 
the IgG solution was neutralized with $\mathrm{NaOH}$ soiution or neutral buffer solution.

\section{Difference spectrum}

Difference spectra were recorded with a Shimazu automatic recording spectrophotometer model UV-240. The $\mathrm{pH}$ of $\mathrm{IgG}$ monomer solution $(1.4 \mathrm{mg} / \mathrm{ml})$ in test tubes was adjusted serially from 1.6 to 7.0 , and all the test tubes were allowed to stand for $60 \mathrm{~min}$ at $25^{\circ} \mathrm{C}$. The absorbance of the $\mathrm{pH}$-treated solution at a given $\mathrm{pH}$ was read against the same solution at $\mathrm{pH}$ 1.6. Then the $\mathrm{pH}$ of the solution was recorded with a Hitachi-Horiba $\mathrm{pH}$ meter model F-7.

\section{Plasmin digestion}

To $1 \mathrm{ml}$ of IgG solution in PBS $(2.8 \mathrm{mg} / \mathrm{ml}), 0.1 \mathrm{ml}$ of plasmin solution (5 casein units $/ \mathrm{ml}$ ) or the same volume of PBS (for blank test) was added and the mixture was incubated at $28^{\circ} \mathrm{C}$ for $3.5 \mathrm{hr}$. After incubation, an equal volume of ammonium sulfate solution $(80 \%$ saturated, $\mathrm{pH} 7.0$ ) was added and the mixture allowed to stand at $4^{\circ} \mathrm{C}$ for $30 \mathrm{~min}$ followed by centrifugation at $3,000 \mathrm{rpm}$ for $10 \mathrm{~min}$ to obtain a clear supernatant. Absorbances at $280 \mathrm{~nm}(\mathrm{~A} 280 \mathrm{~nm})$ of the supernatant and the original IgG solution were measured and the amount digested was calculated by the following formula:

$$
\text { Plasmin digestion }(\%)=\frac{\mathrm{A} 280 \mathrm{~nm} \text { (after digestion)-A280 } \mathrm{nm} \text { (before digestion) }}{\mathrm{A} 280 \mathrm{~nm} \text { (original } \mathrm{IgG})} \times 100
$$

\section{Antigen-antibody complex}

Acid treated IgG $(\mathrm{pH} 7.3,0.36 \mathrm{mg} / \mathrm{ml})$ was mixed with an equal volume of the antigen solution at an optimum concentration and incubated at $37^{\circ} \mathrm{C}$ for $1 \mathrm{hr}$ and then at $4^{\circ} \mathrm{C}$ for another hr. Immune complex thus prepared was tested for anticomplementary activity.

\section{Anticomplementary activity}

Sucrose gelatine veronal buffer (SGVB), pH 7.3, was prepared as follows: 5.5diethylbarbituric acid sodium salt $(1.019 \mathrm{~g}), \mathrm{NaCl}(4.98 \mathrm{~g})$, sucrose $(39.126 \mathrm{~g})$, gelatine $(1.0 \mathrm{~g})$, $\mathrm{CaCl}_{2} \cdot 2 \mathrm{H}_{2} \mathrm{O}(22.0 \mathrm{mg}), \mathrm{MgCl}_{2} \cdot 6 \mathrm{H}_{2} \mathrm{O}(101.5 \mathrm{mg})$ and $\mathrm{N}-\mathrm{HCl}(3.5 \mathrm{ml})$ in a volue made to total 1 liter with distilled water.

A sample solution $(0.4 \mathrm{ml}), 2$ units guinea pig complement $(0.4 \mathrm{ml})$ and SGVB $(1.8 \mathrm{ml})$ was mixed in a test tube and the mixture was incubated for $60 \mathrm{~min}$ at $37^{\circ} \mathrm{C}$. Then, sensitized erythrocytes in SGVB $(0.4 \mathrm{ml})$ were added to the test tube and the tube was incubated with gentle stirring for $60 \mathrm{~min}$ at $37^{\circ} \mathrm{C}$. After incubation, cells were pelleted and the supernatant was monitored spectrophotometrically $(541 \mathrm{~nm})$ for hemoglobin release. Anticomplementary activity was calculated by the following formula and expressed in $\%$ of hemolysis inhibition:

$$
\% \text { of hemolysis inhibition }=\frac{\mathrm{A} 541 \mathrm{~nm}(\mathrm{IgG})-\mathrm{A} 541 \mathrm{~nm}(\mathrm{IgG}+\text { antigen })}{\mathrm{A} 541 \mathrm{~nm}(\text { buffer })} \times 100
$$

\section{Antigen binding activity}

Antigen binding activity was assayed by the parallel line passive hemagglutination (PHA) method using antigen sensitized sheep red blood cells (Uemura et al. 1980).

\section{Chromatography on Staphylococcus protein $A$}

Protein A Sepharose CL-4B (Pharmacia Fine Chemicals, Uppsala, Sweden) was packed in a column and washed with $\mathrm{PBS}, \mathrm{pH}$ 7.0. On a column containing $0.7 \mathrm{ml}$ of gel, $7 \mathrm{mg}$ of IgG was loaded at a flow rate of $3 \mathrm{ml} / \mathrm{hr}$, and unabsorbed IgG was recovered by washing with PBS. 


\section{Protein concentration}

The absorbance at $280 \mathrm{~nm}$ in $1 \mathrm{~cm}$ light pass was measured. The absorbance of $\operatorname{IgG}$ solution was 1.40 per $\mathrm{mg}$ protein determined by Kjeldhal's method and this factor was applied to all samples in estimating protein concentration.

\section{Results}

\section{Separation of aggregated and monomeric IgG fractions}

Aggregated and monomeric IgG fractions were obtained by gel filtration. Fig. 1 shows the results of a typical experiment. As designated in Fig. 1, aggregated fractions and monomeric fractions were pooled individually. Analysis of the pooled fractions by HPLC showed that the monomeric fraction consisted of

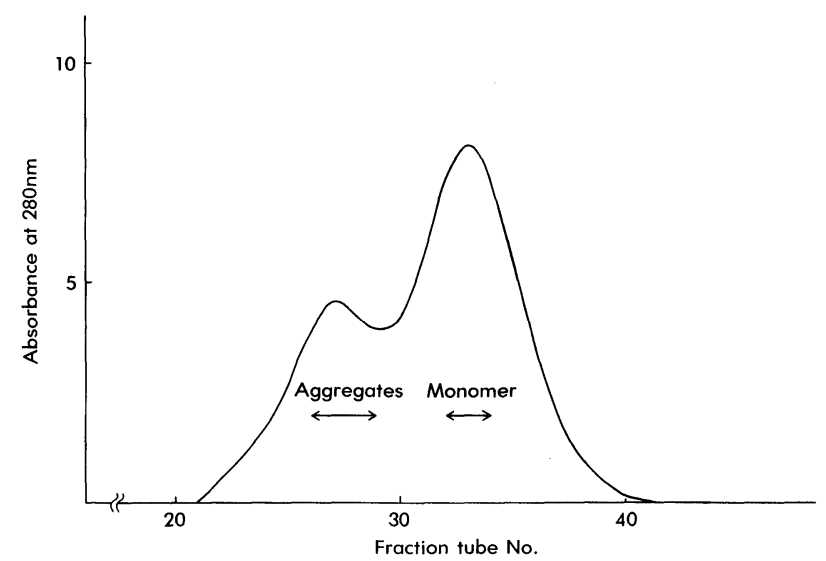

Fig. 1. Gel filtration of human IgG on Sephadex G-200. Human IgG preparation for intramuscular use was applied on a column $(2.5 \times 90 \mathrm{~cm})$ at a flow rate of $25 \mathrm{ml} / \mathrm{hr}$ and at $4^{\circ} \mathrm{C}$. Fractions of $6.7 \mathrm{ml}$ were collected and the absorbance at $280 \mathrm{~nm}$ was determined. Aggregate and monomer fractions indicated by arrows were pooled individually.

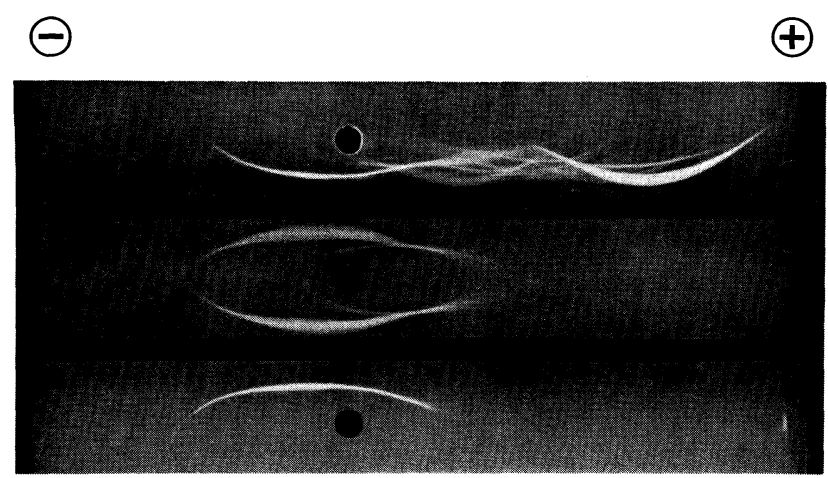

Human serum

Aggregates

fraction

Monomer

fraction

Fig. 2. Immunoelectrophoresis of the aggregated and monomer fractions isolated by gel filtration using anti-human serum (rabbit). 
$98 \%$ monomer and $2 \%$ dimer, and the aggregated fraction consisted of $38-55 \%$ monomer and $62-45 \%$ dimer. In the immunoelectrophoretic test using antihuman serum (rabbit), the monomeric fraction revealed a single and IgG specific precipitin line and no detectable traces of any other proteins (Fig. 2). The aggregated fraction revealed two precipitin lines, i.e. one was identical to IgG and the other to IgA. The concentration of IgA contaminated in the aggregated IgG fraction was $3 \%$ of the total protein. The aggregated and monomeric fractions thus obtained were dialyzed against $0.05 \mathrm{M} \mathrm{KCl}$ containing $0.2 \% \mathrm{PEG}, \mathrm{pH} 7.0$, for $24 \mathrm{hr}$ at $4^{\circ} \mathrm{C}$ and diluted with the same solution to obtain a suitable IgG concentration for the following studies.

\section{Dissociation of IgG aggregates by acid treatment}

The $\mathrm{pH}$ of the IgG aggregate fraction $(5.7 \mathrm{mg} / \mathrm{ml})$ was adjusted to $2.7 \sim 6.9$ with $\mathrm{HCl}$, incubated for $60 \mathrm{~min}$ at $28^{\circ} \mathrm{C}$ and then neutralized with $\mathrm{NaOH}$. The acid treated IgG solutions were diluted with equal volumes of PBS, $\mathrm{pH} 7.0$, and tested for HPLC and plasmin digestion. The aggregated fraction used in this study consisted of $38 \%$ monomer, $61 \%$ dimer and $1 \%$ polymer before acid treatment. As shown in Fig. 3, lowering $\mathrm{pH}$ resulted in an increase in monomer content and a decrease in dimer content. However, the polymer content increased apparently at $\mathrm{pHs}$ below 3.8. Plasmin digestion was performed after the neutralization. Fig. 3 shows that the percentage digestion was minimum at a $\mathrm{pH}$ range of $3.8-4.0$ and higher at $\mathrm{pH}$ values below 3.8 or above 4.0 , where the concentrations of polymer or dimer were higher than those at $\mathrm{pH} 3.8-4.0$. In the

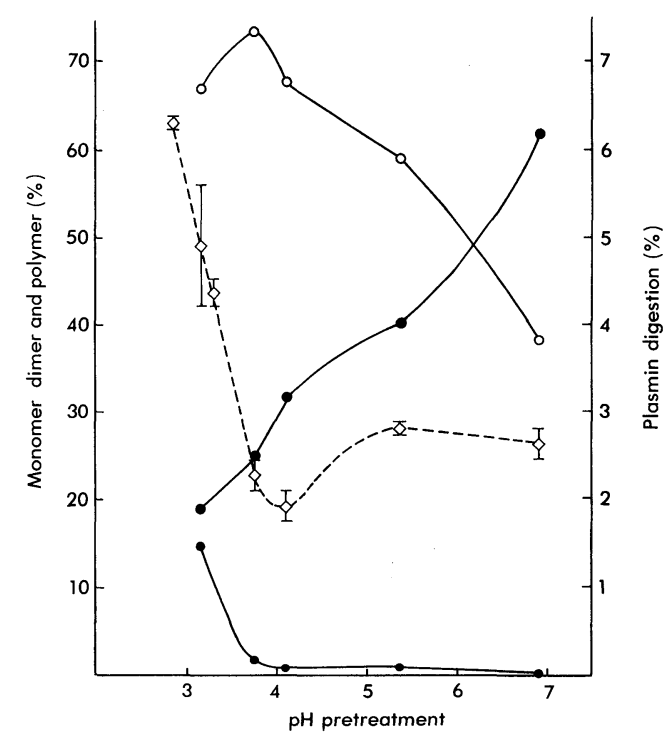

Fig. 3. Dissociation of $\operatorname{IgG}$ aggregates by acid treatment. Aggregate fractions were treated at various acidic $\mathrm{pHs}$ at $28^{\circ} \mathrm{C}$ for 60 min and neutralized.

Monomer (-०-), dimer (- - ) and polymer (- - ) concentrations, and plasmin digestion ratio $(---\diamond---)$ were determined. 


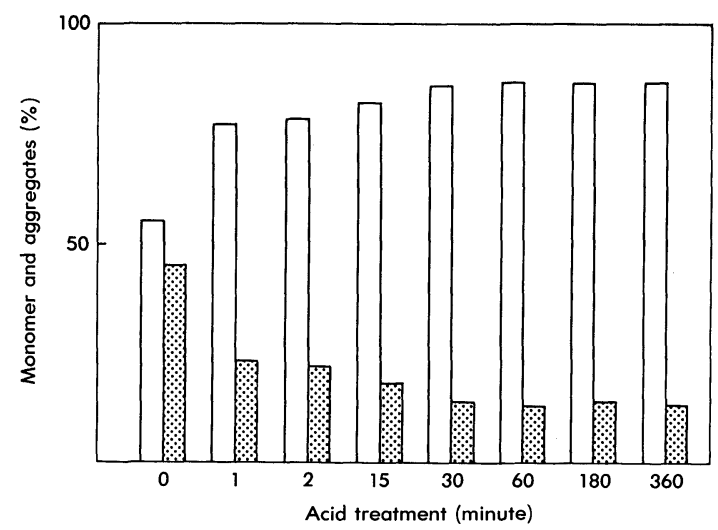

Fig. 4. Time-cource of dissociation of IgG aggregates at $\mathrm{pH}$ 3.8. IgG aggregate fractions were adjusted to $\mathrm{pH} 3.8$ at $28^{\circ} \mathrm{C}$, and diluted five times with PBS for neutralization at indicated times. Concentration of $\operatorname{IgG}$ monomer ( $\square$ ) and aggreagates ( were determined by the HPLC method.

next experiment, time course of the dissociation at acidic $\mathrm{pH}$ was studied. The $\mathrm{pH}$ of the aggregated fraction in the test tube was adjusted to 3.8 at $28^{\circ} \mathrm{C}$ and a $0.2 \mathrm{ml}$ portion was transferred into 5 times this amount of PBS for neutralization. The percentage contents of nomomer and aggregates as revealed by the HPLC method are shown in Fig. 4. Before acid treatment, the contents of monomer and aggregates in the aggregated fraction were $55 \%$ and $45 \%$, respectively. The monomer content increased to $77 \%$ after $1 \mathrm{~min}$ and reached a plateau within 30 min, but about $13 \%$ of the aggregates still remained after $360 \mathrm{~min}$. Judging from the results so far obtained, it may be concluded that the optimum $\mathrm{pH}$ range for the dissociation of IgG aggregates is 3.8-4.0, and that the dissociation occurs rapidly and reaches a plateau after $30 \mathrm{~min}$. To determine whether the acid treated IgG undergoes denaturation or not, the acid stability of human IgG was studied.

\section{Acid difference spectum}

Fig. 5 shows typical difference spectra of human IgG monomer fraction at indicated $\mathrm{pHs}$ against the same solution at $\mathrm{pH}$ 1.6. Two peaks and one shoulder was observed at $292 \mathrm{~nm}, 285 \mathrm{~nm}$ and $278 \mathrm{~nm}$, respectively. The height of the two peaks at $292 \mathrm{~nm}$ and $285 \mathrm{~nm}$ increased with increasing $\mathrm{pH}$. Fig. 6 shows the values of absorbance of the peak at $292 \mathrm{~nm}$ as a function of $\mathrm{pH}$. The values fell sharply at $\mathrm{pH}$ below 3.8 indicating acid denaturation. The reversibility of the acid denaturation of IgG monomer was studied as follows: The IgG monomer fraction $(1.4 \mathrm{mg} / \mathrm{ml})$ was adjusted to $\mathrm{pH} 2.4-5.2$ and allowed to stand for $60 \mathrm{~min}$ at $25^{\circ} \mathrm{C}$, and then neutralized with $\mathrm{NaOH}$. After additional incubation for $20 \mathrm{hr}$ at $4^{\circ} \mathrm{C}$, the absorbance was measured against a protein solution at $\mathrm{pH} 1.6$, at $25^{\circ} \mathrm{C}$. The absorbance values at $292 \mathrm{~nm}$ were similar to those obtained with protein that was not exposed to acid prior to the measurement. 


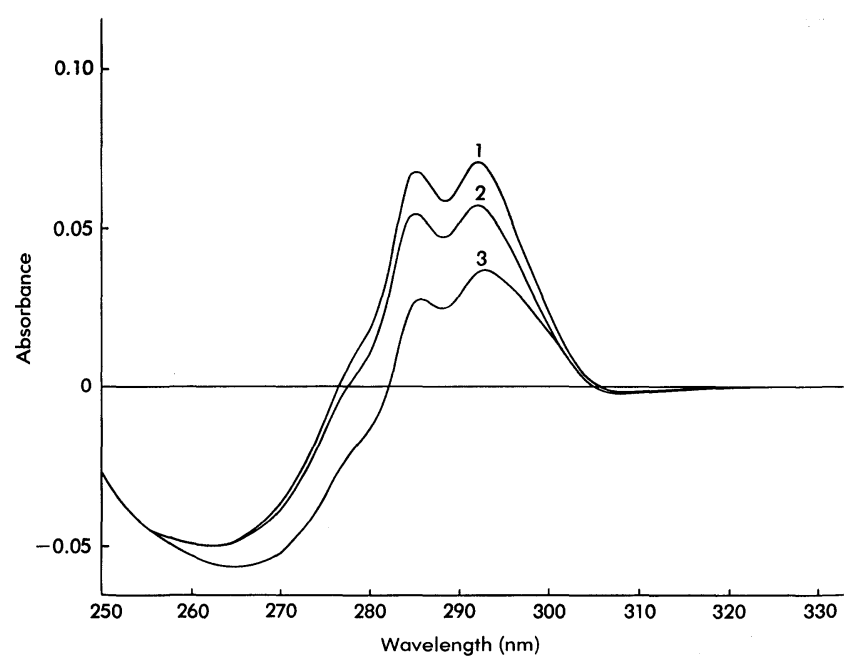

Fig. 5. Acid difference spectra of IgG monomer.

Reference: IgG monomer in $0.05 \mathrm{M} \mathrm{KCl}$ containing $0.2 \%$ PEG (pH 1.6). 1, pH 5.4; 2, pH $3.2 ; 3$, pH 2.7 .

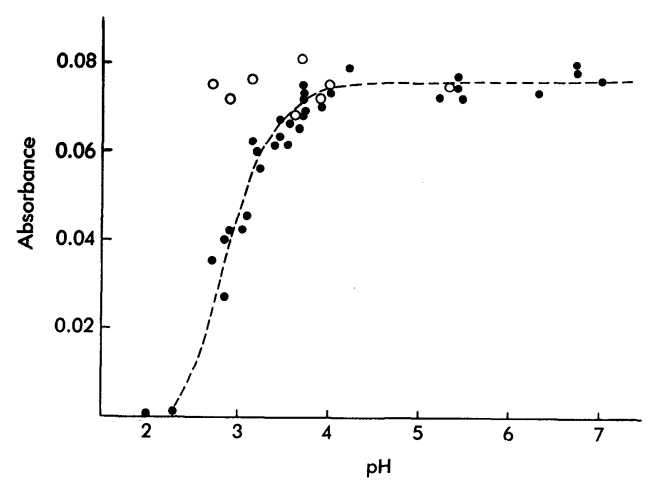

Fig. 6. Absorbance at $292 \mathrm{~nm}$ as a function of $\mathrm{pH}$. The values measured at a given $\mathrm{pH}$ and at neutral $\mathrm{pH}$ after exposure to a given $\mathrm{pH}$ are shown by closed and open circles, respectively. Reference: IgG monomer in $0.05 \mathrm{M}$ $\mathrm{KCl}$ containing $0.2 \% \mathrm{PEG}$ ( $\mathrm{pH}$ 1.6).

\section{Change in molecular weight}

An IgG monomer fraction $(1.4 \mathrm{mg} / \mathrm{ml})$ was incubated at acidic $\mathrm{pHs}$ for $60 \mathrm{~min}$ at $28^{\circ} \mathrm{C}$, neutralized with $\mathrm{NaOH}$ and allowed to stand for $20 \mathrm{hr}$ at $4^{\circ} \mathrm{C}$. Turbidity was observed macroscopically at $\mathrm{pH}$ below 3.0. The molecular weight and concentration of IgG monomer remained unchanged at $\mathrm{pH}$ 3.3-7.0, but IgG monomer concentration decreased to $70 \%$ and a significant amount of polymer appeared at $\mathrm{pH}$ below 3.0 (Fig. 7).

\section{Plasmin digestion}

An IgG monomer fraction $(5.7 \mathrm{mg} / \mathrm{ml})$ was incubated at acidic $\mathrm{pH}$ and neutralized as described above. Plasmin digestion obviously accelerated at $\mathrm{pHs}$ 


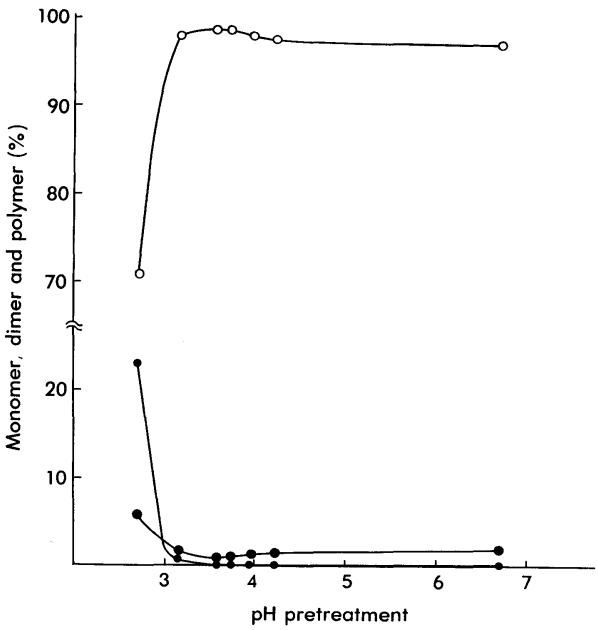

Fig. 7

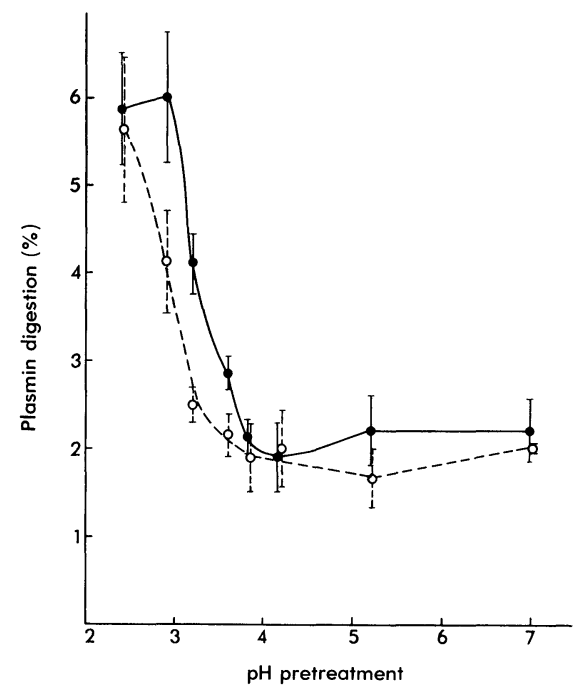

Fig. 8

Fig. 7. Change in molecular weight after acid treatment. IgG monomer fractions were treated at various $\mathrm{pHs}$ for $60 \mathrm{~min}$ at $28^{\circ} \mathrm{C}$ and neutralized. The monomer (- - -), dimer (-•-) and polymer (-.-) concentrations were measured by the HPLC method.

Fig. 8. Plasmin digestion ratio after acid treatment. IgG monomer fractions were treated at various $\mathrm{pHs}$ for $60 \mathrm{~min}$ at $28^{\circ} \mathrm{C}$ and neutralized. One (- - ) and 24 (------) hr after neutralization, plasmin digestion tests were performed.

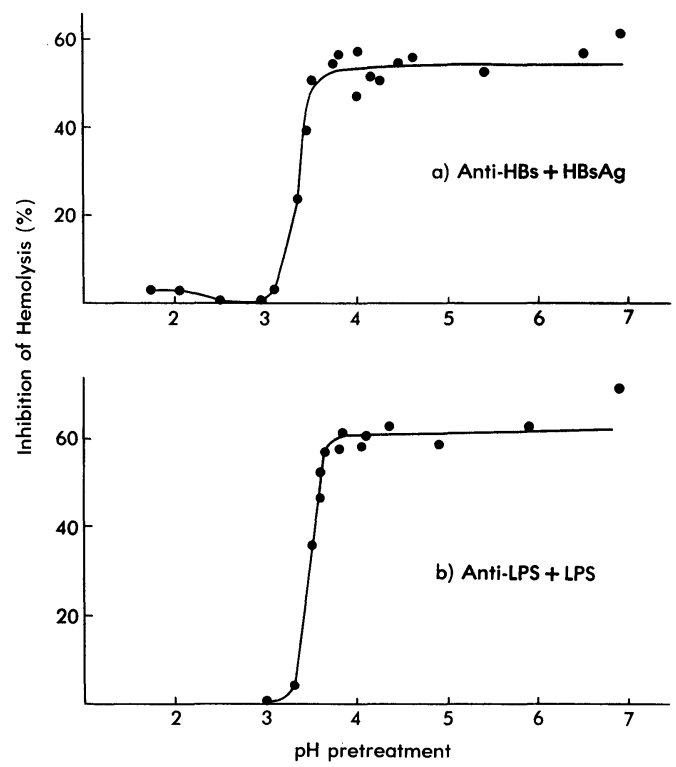

Fig. 9. Change in complement binding activity after acid treatment. Acid treated IgG solution ( $\mathrm{pH}$ 7.3) was incubated with the corresponding antigen solution at an optimum concentration to form immune complex. The anticomplementary activity of the complex was then measured. 
below 3.5, and the plasmin digestion-pH pretreatment curve obtained $24 \mathrm{hr}$ after neutralization shifted slightly to acidic range as compared to that $1 \mathrm{hr}$ after neutralization (Fig. 8). That human IgG monomer undergoes denaturation below $\mathrm{pH}$ 3.5-3.7 was also confirmed by subsequent studies.

\section{Complement binding activity}

IgG monomer fractions $(3.6 \mathrm{mg} / \mathrm{ml})$ were obtained from hyperimmune antiHBs and anti-LPS globulin preparations. The two IgG monomer fractions were treated individually at acidic $\mathrm{pHs}$ for $60 \mathrm{~min}$ at $28^{\circ} \mathrm{C}$ and diluted 10 times with SGVB for neutralization. The acid-treated hyperimmune IgG solutions $(0.36 \mathrm{mg} / \mathrm{ml})$ were incubated with the corresponding antigen solutions at optimum concentrations to produce the immune complexes. Fig. 9 shows that anticomplementary activities of the immune complexes were constant during the test over the $\mathrm{pH}$ range of 3.77.0, but sharply decreased at $\mathrm{pH}$ below 3.6 indicating the denaturation of $\mathrm{IgG}$ monomer at the Fc region.

\section{Antigen binding activity}

Acid treatment of IgG monomers was performed by a method similar to that reported in Fig. 9. As judged by their ability to bind antigen which were

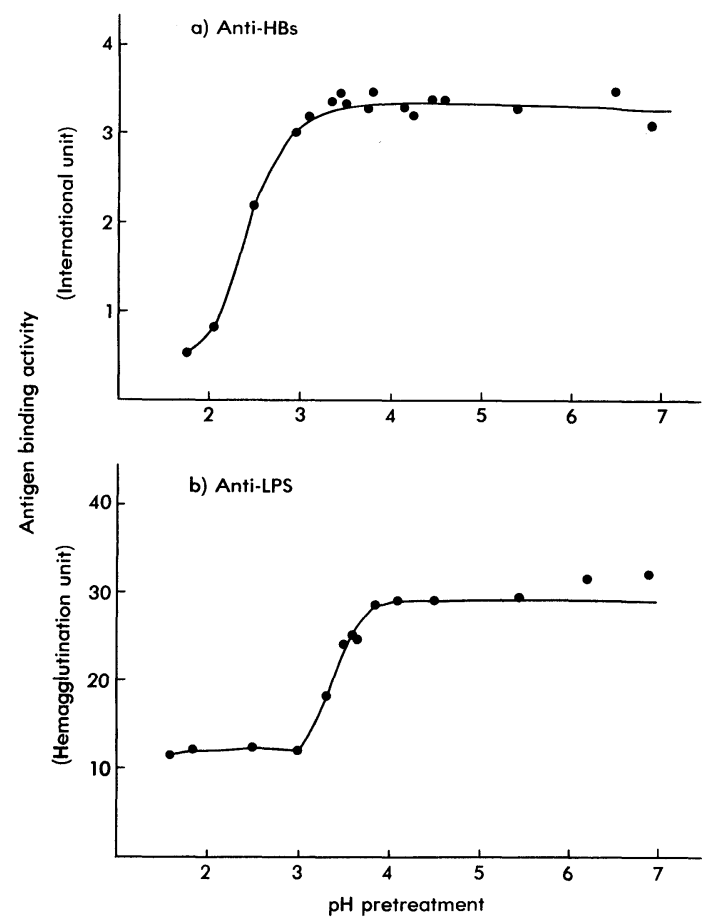

Fig. 10. Change in antigen binding activity after acid treatment. IgG monomer fraction was treated at various $\mathrm{pHs}$ for $60 \mathrm{~min}$ at $28^{\circ} \mathrm{C}$ and neutralized. Remaining antigen binding activity was measured by the parallel line PHA method. 
sensitized on red cells, acid treatment at $\mathrm{pH} 3.7$ did not affect the antigen binding sites, viz., Fab regions. In case of anti-HBs globulin, the activity did not decrease even after $\mathrm{pH} 3.0$ treatment (Fig. 10).

\section{Protein $A$ binding activity}

Since the absorbing capacity of the protein A-Sepharose column used in my experiment was found to be about $10-15 \mathrm{mg} / \mathrm{ml}$ gel, $7 \mathrm{mg}$ of acid treated IgG was applied on the column, and the amount of unabsorbed IgG that might correspond to the sum of $\mathrm{IgG}_{3}$ and denatured $\mathrm{IgG}$ was determined by the single radial immune diffusion method. As shown in Fig. 11, the binding ability of IgG to protein A was not affected by acid treatment at $\mathrm{pH}$ above 3.7 .

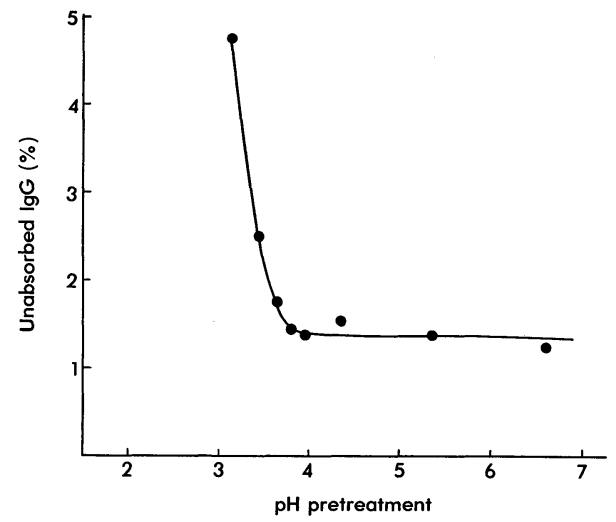

Fig. 11. Change in protein A binding activity after acid treatment. Acid treated IgG solution ( $\mathrm{pH} 7.0$ ) was applied on a protein A-Sepharose column (7 mg IgG/0.7 ml gel) and washed with PBS. IgG concentration in the unabsorbed fraction was measured by the single radial immune diffusion method.

\section{Discussion}

Intramuscular IgG preparation used in the present study contained about $30 \%$ aggregated IgG and this percentage conformed to a previous report (Römer et al. 1982). The aggregates in the IgG preparation was thought to be formed by denaturation occurring at ethanol fractionation and freezing-thawing in the purification processes.

Though ideal dissociation of the aggregated IgG was found to occur at $\mathrm{pH}$ 3.84.0, a part of the aggregates still remained after the acid treatment. The author suppose that the persistent aggregates are composed mainly of deep-denatured IgG, but further studies are required to explain this phenomenon.

In acid difference spectrum studies, Bence Jones protein showed three peaks at 279, 286 and $293.5 \mathrm{~nm}$ (Takahashi et al. 1790). But, in the case of human IgG monomer, the absorbance at $279 \mathrm{~nm}$ was not clear and seen only as a shoulder. The change in the absorbance at $292 \mathrm{~nm}$ with $\mathrm{pH}$ illustrated in Fig. 6 showed that human monomer IgG underwent acid denaturation at $\mathrm{pH}$ below 3.8, but the denaturation determined by this method was reversible.

The molecular weight of human IgG measured at $\mathrm{pH} 3.0$ was smaller than $7 \mathrm{~S}$, but it returned to $7 \mathrm{~S}$ after neutralization and a small amount of insoluble materials appeared in the IgG solution (Hansson 1968). The human IgG monomer fraction 
showed turbidness after acid treatment at $\mathrm{pH}$ below 3.0, too, and the supernatant contained polymers indicating denaturation. However, the molecular weight of the IgG treated at $\mathrm{pH}$ 3.3-7.0 was identical to that of the native one. The relationship between $\operatorname{IgG}$ subclasses and the tendency to denature or polymerize during acid treatment will be examined in the future.

In general, the sensitivity of proteins to protease increases after denaturation (Linderström-Lang et al. 1938). For example, rabbit IgG in native form is resistant to plasmin but the sensitivity increases after acid denaturation (Connel and Porter 1971; Stewart and Stanworth 1975). Since the sensitivity of human IgG monomer to plasmin increased after acid treatment below $\mathrm{pH} 3.7$ as illustrated in Fig. 8, the IgG might undergo some denaturation by acid treatment, and the denaturation might be slightly reversible at neutral $\mathrm{pH}$.

Besides antigen binding activity, complement binding activity is one of the important biological properties of immune globulins. Fab and $\mathrm{F}\left(\mathrm{ab}^{\prime}\right)_{2}$ have antigen binding but not complement binding activities, so the bacteriolytic activity in the presence of complement are remarkably inferior to that of native IgG (Doi et al. 1978). Studies on acid treatment of rabbit IgG showed that the antigen binding activity survived but not the complement binding activity (Stollar et al. 1976; Winkelhake et al. 1980). In the present study, the antigen binding activity of human IgG monomers survived acid treatment at $\mathrm{pH} 3.0-3.5$ but the complement binding activity was reduced by the treatment. This phenomenon may correlate with the phenomenon that $\mathrm{Fab}$ and $\mathrm{F}(\mathrm{ab})_{2}$ fragments were more stable than Fe fragment in acidic condition (Abaturov et al. 1969; Charlwood and Utsumi 1969).

When anti-HBs and anti-LPS globulins used in the present studies were separated individually into electrophoretically slow and fast IgG fractions by an ion exchange chromatography method (Uemura et al. 1975), the anti-HBs and antiLPS activities were distributed mainly in the slow and fast IgG fractions, respectively (data not shown). This suggests that the slow IgG (anti-HBs) and fast IgG (anti-LPS) may have similar stability in acidic conditions.

$\mathrm{IgG}_{1}, \mathrm{IgG}_{2}$ and $\mathrm{IgG}_{4}$ but not $\mathrm{IgG}_{3}$ bind to protein $\mathrm{A}$ at $\mathrm{C}_{\mathrm{H}} 3$ and $\mathrm{C}_{\mathrm{H}} 2$ domeins (Stewart et al. 1978). When the Fc region of IgG was modified chemically with $\beta$-propiolactone, the binding activity decreased appreciably (Skvaril et al. 1980; Ceska 1981). Decrease in binding activity of acid treated IgG at pH below 3.7 to protein $\mathrm{A}$ also means acid denaturation. In other words, acid treatment at $\mathrm{pH}$ above 3.7 does not denature human IgG.

The biological half-life of acid treated $\operatorname{IgG}(\mathrm{pH} 4)$ was similar to that of IgG, but those of sulfonated and $\beta$-propiolactone treated ones were shorter than that of the above two (Morell et al. 1980). These in vivo results also suggest that acid treatment at $\mathrm{pH} 3.8-4.0$ does not alter the properties of human IgG.

On the basis of these results, the author concludes that a $\mathrm{pH}$ value of $3.8 \sim 4.0$ is reasonable for the dissociation of aggregated IgG and that human IgG does not undergo denaturation at this condition. 


\section{Acknowledgments}

I thank Professor N. Ishida, Department of Bacteriology, Tohoku University School of Medicine for his guidance and helpful advice, and Dr. T. Suyama and Dr. S. Funakoshi, Central Research Laboratory, the Green Cross Coporation for their encouragement.

\section{References}

1) Abaturov, L.V., Nezlin, R.S., Vengerova, T.I. \& Varshavsky, J.M. (1969) Conformational studies of immunoglobulin $\mathrm{G}$ and its subunits by the methods of hydrogendeuterium exchange and infrared spectroscopy. Biochim. biophys. Acta, 194, 386-396.

2) Ceska, M. (1981) Binding of protein A to some human gammaglobulins used intravenously. Vox Sang., 40, 395-402.

3) Charlwood, P.A. \& Utsumi, S. (1969) Conformation changes and dissociation of Fc fragments of rabbit immunoglobulin $\mathrm{G}$ as a function of pH. Biochem. J., 112, 357-365.

4) Christian, C.L. (1960) Studies of aggregated $\gamma$-globulin. I. Sedimentation, electrophoretic and anticomplementary properties. J. Immunol., 84, 112-116.

5) Connel, G.E. \& Porter, R.R. (1971) A new enzymic fragment (Facb) of rabbit immunoglobulin G. Biochem. J., 124, 53p.

6) Deutsch, D.G. \& Mertz, E.T. (1970) Plasminogen: Purification from human plasma by affinity chromatograpy. Science, 170, 1095-1096.

7) Doi, E. \& Jirgensons, B. (1970) Circular dichroism studies on the acid denaturation of $\gamma$-immunoglobulin $\mathrm{G}$ and its fragments. Biochemistry, 9, 1066-1073.

8) Doi, T., Nakajima, T., Nishida, M. \& Suyama, T. (1978) Effect of intravenously applicable globulin on phagocytosis of bacteria by human polymorphonuclear leukocytes. Chem. Pharm. Bull., 26, 3492-3497.

9) Fey, H. (1975) A simple procedure for the production of Fab from bovine IgG as an absorbent in the preparation of class-specific anti-immunoglobulin. Immunochemistry, 12, 235-239.

10) Funakoshi, S., Ohmura, T., Tajima, M., Kinoshita, K., Matsumoto, T. \& Suyama, T. (1981) Hepatitis B vaccine - The production and testing. Hepatitis $B$ Vaccine INSERM Symposium, 18, 57-66.

11) Hansson, U.B. (1968) Inhibition and reversal of aggregation of immunoglobulin $\mathrm{G}$ by freezing. Acta chem. scand., 22, 490-496.

12) Henney, C.S. \& Ellis, E.F. (1968) Antibody production to aggregated human $\gamma \mathrm{G}$ globulin in acquired hypogammaglobulinemia. New. Engl. J. Med., 278, 1144-1146.

13) Hsiao, S. \& Putnam, F.W. (1961) The cleavage of human $\gamma$-globulin by papain. $J$. biol. Chem., 236, 122-135.

14) Ishizaka, T. \& Ishizaka, K. (1959) Biological activities of aggregated gamma globulin I. Skin reactive and complement-fixing properties of heat denatured gamma globulin. Porc. Soc. exp. Biol. Med., 101, 845-850.

15) Linderström-Lang, K., Hotchikss, R.D. \& Johansen, G. (1938) Peptide bonds in globular proteins. Nature, $142,996$.

16) Morell, A., Schürch, B., Ryser, D., Hofer, F., Skvaril, F. \& Barandun, S. (1980) In vivo behaviour of gamma globulin preparations. Vox Sang., 38, 272-283.

17) Römer, J., Morgenthaler, J.J., Scherz, R. \& Skvaril, F. (1982) Characterization of various immunoglobulin preparations for intravenous application. Vox Sang., 42, $62-73$.

18) Sgouris, J.T., Inman, J.K., McCall, K.B. \& Anderson, H.D. (1961) The evaluation of fibrinolytic preparations. Vox Sang., 6, 53-59.

19) Skvaril, F., Roth-Wicky, B. \& Barandun, S. (1980) IgG subclasses in human $\gamma$-globulin preparation for intravenous use and their reactivity with staphylococcus protein A. Vox Sang., 38, 147-155.

20) Stewart, G.A. \& Stanworth, D.R. (1975) The effect of acid treatment upon the susceptibility of rabbit IgG to proteolytic cleavage with various enzymes. Immunochemistry, 12, 713-721. 
21) Stewart, G.A., Varro, R. \& Stanworth, D.R. (1978) The influence of enzymatic cleavage and chemical modification of human and rabbit IgG on their reactivity with staphylococcal protein A. Immunology, 35, 785-791.

22) Stollar, B.D., Stadecker, M.J. \& Morecki, S. (1976) Comparison of the inactivation of IgM and IgG complement fixation sites by acid and base. J. Immunol., 117, 13871391 .

23) Takahashi, H., Hirai, T., Azuma, T., Hamaguchi, K. \& Migita, S. (1970) pH-Dependent conformation change of a Bence Jones protein. J. Biochem., 67, 795-799.

24) Uemura, Y., Uriyu, K., Funakoshi, S. \& Suyama, T. (1975) Study on plasmin treated immunoglobulin. J. Jap. Soc. Blood Transfus., 23, 180. (Japanese)

25) Uemura, Y., Uriyu, K., Funakoshi, S., Saito, H. \& Kurokawa, M. (1980) Parallel line assay of potency of anti-HBs immunoglobulin by macro-PHA method. $J$. Jap. Soc. Blood Transfus., 27, 127-129. (in Japanese with English abstract)

26) Westphal, O., Luderitz, O. \& Bister, F. (1952) Über die Extraction von Bakterien mit Phenolwasser. Z. Naturforsch. Teil B, 76, 148-155.

27) Winkelhake, J.L., Kunicki, T.J., Elcombe, B.M. \& Aster, R.H. (1980) Effects of pH treatments and deglycosylation of rabbit immunoglobulin $\mathrm{G}$ on the binding of $\mathrm{C}_{\mathbf{1 q}} \cdot J$. biol. Chem., 255, 2822-2828. 